\title{
What healthcare professionals owe us: why their duty to treat during a pandemic is contingent on personal protective equipment (PPE)
}

\author{
Udo Schuklenk
}

\section{Correspondence to} Dr Udo Schuklenk, Department of Philosophy, Queen's University, Kingston, ON K7L 3N6, Canada; udo.schuklenk@pm.me

Received 7 April 2020 Revised 13 April 2020 Accepted 16 April 2020 Published Online First 12 May 2020

\section{Check for updates}

(C) Author(s) (or their employer(s)) 2020. No commercial re-use. See rights and permissions. Published by BMJ.

To cite: Schuklenk U.

$J$ Med Ethics

2020;46:432-435.

\section{ABSTRACT}

Healthcare professionals' capacity to protect themselves, while caring for infected patients during an infectious disease pandemic, depends on their ability to practise universal precautions. In turn, universal precautions rely on the availability of personal protective equipment (PPE). During the SARS-CoV2 outbreak many healthcare workers across the globe have been reluctant to provide patient care because crucial PPE components are in short supply. The lack of such equipment during the pandemic was not a result of careful resource allocation decisions in the global north, where the short supply could be explained through their high cost. Instead, they were the result of democratically elected governments prioritising low tax regimes over an adequate resourcing of their healthcare delivery systems. Such decisions were made despite global health experts warning about the high probability of pandemics like SARS-CoV2 occurring during our lifetimes. Avoidable allocation decisions by democratically elected political leaders resulted in a lack of sufficient PPE for healthcare professionals. After discussing and discounting various ethical arguments in support of a professional obligation to treat, even without or with suboptimal PPE, I conclude that these policy decisions were sufficiently grave that they provide a sound ethical rationale to justify healthcare workers' refusal to provide care to infected patients.

\section{INTRODUCTION}

During the SARS-CoV2 pandemic many doctors and nurses have been reluctant to provide care to COVID-19 patients. The UK's doctors' leaders have warned repeatedly that the lack of appropriate PPE puts doctors' lives at risk. ${ }^{1}$ PPE levels in Australia's state of Queensland were very low, noted the state's Clinical Senate Chair Alex Markwell. ${ }^{2}$ Bulgaria has seen a wave of doctors and nurses resigning at two hospitals in the country's capital ${ }^{3}$ over the lack of access to PPE, Zimbabwean doctors and nurses have reportedly gone on strike over the lack of protective equipment, ${ }^{4}$ and nurses across the USA have protested about the lack of PPE. ${ }^{5}$ These healthcare workers had every reason to be concerned for their own well-being. At the time of writing 100 doctors who provided care to Italian COVID-19 patients have died as a result of contracting SARS-CoV2 on the job. ${ }^{6}$ Many more have fallen very seriously sick. A list of 'Fallen Coronavirus Heroes' maintained by Michael C Gibson, a medical doctor, lists (on 5 April 2020) 136 healthcare professionals who lost their lives as a result of COVID-19 infections they acquired while caring for infected patients. ${ }^{7}$ The number is now almost certainly significantly higher, and it is bound to increase daily for some time to come. Despite some effort I have failed to track down a list looking at COVID-19 care-related deaths of other healthcare workers, such as nurses. However, there can be no doubt that the death toll among healthcare professionals caring for COVID-19 patients all over the world will be significant.

In response to concerns about the availability of healthcare professionals during expected COVID-19 case surges, a state government in one of Germany's most populous states, North-Rhine Westphalia, seriously considered introducing a compulsory service obligation for healthcare professionals. ${ }^{8}$ Little did doctors know, when they joined the profession, that at some point further down the road, government would be planning to draft them into compulsory service, much like soldiers. Desperate governments around the globe have come up with their own policies and ethics documents looking at the question of whether healthcare workers have a professional duty of care under the circumstances. Remarkably, they were haphazardly put together during the pandemic, and there was no preparation in any of the countries mentioned thus far. It is probably a sign of the times that the bar these documents set for a justifiable refusal to work is extraordinarily high. This suits those writing them. In all earnestness the Canadian province of British Columbia issued an ethics document that, while arguably producing conflicting guidance, could be interpreted as the view that healthcare workers do have an obligation to provide care if and only if they do not face 'certain and significant harm'. ${ }^{9}$ The guidance is based on a pandemic influenza ethical guidance document ${ }^{10}$ that shows a flaw that is replicated in many other documents of this kind. ${ }^{11}$ It proffers a collection of disparate ethical values to consider, a vegetable garden equivalent of values, for you to pick and choose the ones that sound nicest. Of course, neither clear action guidance nor action justification can be derived from such documents. Unsurprisingly, while citing the document, and copy-pasting those ethical values, the British Columbia government task force fails to show how it derived its action guidance from said document. In medicine few things are ever certain. Realistically no healthcare workers could demonstrate in advance that they did not just face a risk—even a high risk—of significant harm, but that they would face significant harm with certainty if they were made to work.

\section{WHAT HEALTHCARE PROFESSIONALS OWE US}

What is it then that healthcare professionals owe us in a crisis like the current one? As patients we 
depend on doctors and nurses to provide professional care to us, because they have the specialist training, and they have a monopoly on the provision of these kinds of services. It is not as if we could turn around and go elsewhere if the hospital's intensive care unit has an insufficient number of healthcare workers on call.

Most doctors in their graduation ceremonies take a public oath to serve the public good, oftentimes modelled on the World Medical Association's Declaration of Geneva. ${ }^{12}$ The Declaration is arguably a modern-day Hippocratic Oath. Until the 1994 version of that influential document, doctors promised to provide emergency care, without any ifs, ands or buts. However, that promise has not been repeated in subsequent iterations of that document, ${ }^{13}$ so that approach does not address the question at hand. Perhaps the world's doctors woke up to the dangers of making promises they did not realistically intend to live up to. What do the traditions of the medical profession look like then? As Ariel R Schwartz notes, 'the history of medical ethics reveals that the medical community has never come to a consensus on the nature and scope of its responsibilities during an epidemic'. ${ }^{14}$ His description of the behaviour of doctors during infectious disease outbreaks from the black plague in the 14th and 15th centuries to the bubonic plague in the 17th century suggests a deeply individualistic response. Many ran away to protect themselves; others stayed behind to care for their patients. The same pattern of behaviour held true during the 2014-16 Ebola virus disease outbreaks in West African countries.

Neither the history of how healthcare professionals responded in the past to pandemic outbreaks, nor their professed values, provide us with much guidance on what the professionals themselves take to be their professional obligations. In any case, why would anyone want to leave decisions on what the profession and its members owe to society to the profession? ${ }^{15}$ We have little reason to assume that it won't look after its members first. Medical associations, unlike statutory regulatory bodies, despite protestations to the contrary, are essentially glorified trade unions representing their members' interests. This situation would not be the first where such associations might prioritise their members' interests over the good of society. ${ }^{16}$

One could reasonably argue that there is an implied voluntary consent to risk-taking when healthcare workers accepted the deal their profession cut with society. Monopoly powers, high societal standing and, at least for medical doctors, oftentimes high salaries do not come without a price. Healthcare professionals knew, if they paid attention to the subject in their global health classes, that infections such as severe acute respiratory syndrome (SARS), Middle East respiratory syndrome (MERS), Ebola and others were going to raise their ugly heads during their lifetime, and joining the profession meant accepting a duty to provide care. During the early days of the HIV pandemic, when an infection with that virus meant certain death, regulatory bodies in most countries eventually decreed that healthcare professionals had an obligation to treat. ${ }^{14}$ Given COVID-19's much lower mortality risk, this should settle it, or so one might think. That is a mistaken view.

What makes SARS-CoV2 different is that the HIV response was predicated on the availability of PPE to healthcare professionals. In such a reality, if healthcare professionals followed universal precautions and had the right protective equipment, the odds of them picking up HIV would have been negligible. With SARS-CoV2 we are, in most countries, in a very different situation.

\section{NEOLIBERALISM AND THE FETISHISATION OF 'EFFICIENCY'}

One feature closely linked to the functioning of global capitalism is efficiency. Everybody involved in the value chain aims to avoid the waste of money and resources. There is a virtue in running 'lean' operations. Most countries in the global north, that operate varieties of public or publicly funded healthcare systems, saw the re-election of cost-cutting governments who ran successfully on election campaign platforms promising to 'return money to our back pockets' and away from big government. ${ }^{17}$ This claim certainly is an uncontroversial one for governments elected in countries like the UK, France, Germany, and Australia, to name just a few, during the last few decades. And as taxpayers we did get money returned to our back pockets by low tax regimes. As neoliberal election campaign lore has it, we know best how to spend our hard-earned money. Such policies were anything but cost neutral, as those in need of public services have known for a long time. They succeeded in hollowing out the healthcare delivery infrastructures in most countries. The literature providing evidence to this effect is vast, and it is impossible to do it justice here. ${ }^{18-21}$ There are still appreciable differences between countries; for example, Germany has about 29 intensive care unit (ICU) beds available per 100000 inhabitants, versus 6.5 in the UK. ${ }^{22}$ In the UK, since Prime Minister Margaret Thatcher's tenure, citizens have been treated to decades of low-tax, small-state austerity, effectively rendering the National Health Service (NHS) unable to cover regular influenza season patient case loads without great difficulty. ${ }^{23}$ In the USA, where publicly funded healthcare delivery is close to non-existent and for-profit operators often dictate the levels of care that will be provided, the results were quite similar, except there the availability of and access to healthcare infrastructure was dictated by profit objectives driving many hospitals, as well as for-profit insurers that pay for-profit and non-profit hospitals alike for particular services.

\section{IMPLICATIONS FOR HEALTHCARE PROFESSIONALS' OBLIGATIONS}

The endpoint was the same: democratically elected governments across the global north have left hospitals woefully unprepared for the onslaught of patients, not only in terms of ICU beds and ventilators, but also in terms of PPE. The latter is what matters when we ask ethical questions about healthcare workers' responsibilities during pandemic outbreaks. The unavailability of PPE to efficiently maintain universal precautions while on the job was a foreseeable consequence of the race to the public services bottom that globalisation motivates.

If the lack of available PPE for frontline healthcare professionals would have been due to a natural occurrence, one could reasonably argue that they should be prepared to accept a certain higher degree of risk. The argument in support of such a view could take recourse to the already-mentioned voluntary informed consent argument. Healthcare professionals signed voluntarily a contract with society to provide reliable services, not only when the sun is shining, but also in times of crisis. If there were a situation where, despite society's best efforts at resourcing the protection of its healthcare workers against acquiring lifethreatening infections while on the job, their risk would remain high, one could argue that they ought to accept a certain degree of risk. They knew there was a chance such an outbreak could occur during their lifetime, and part of the deal with society was not that they could refuse the provision of professional care. However, there clearly have to be some limits to such a duty. For instance, society cannot afford to lose a very large number of 
its healthcare workers during a pandemic, because the time will come when the pandemic wave has passed, and doctors will still be needed. It would also be unrealistic to expect doctors to risk their lives if there were a high probability of death, say because the best societal effort at resourcing their protection was still insufficient to protect the workers. Surely then their continuing provision of professional services would constitute a supererogatory kind of action.

In any case, these kinds of arguments have been discussed in the literature for a long time. Whatever one makes of these arguments has no bearing on the current situation. The reason for this is that in the current situation the lack of PPE is truly deliberate, it is by human, cost-cutting design. It is not as if governments and their experts did not know that the occurrence of an agent like SARS-CoV2 or worse was likely. For a specialist audience the US Centers for Disease Control and Prevention issued in 2017 community mitigation guidelines. ${ }^{24}$ In fact, during former President George W Bush's presidency the country went to significant lengths in its global pandemic planning. ${ }^{25}$ Even lay people were able to read up on the issue, in a multitude of media. Understanding the likelihood of something like this to occur during our lifetime did not require a great deal of specialist knowledge. ${ }^{26}$ Given all this, it was quite a remarkable sight to see on global news programmes the UK Chancellor and Prime Minister standing outside 10 Downing Street, wildly applauding their country's healthcare professionals' heroism. ${ }^{27}$ The heroism that they were celebrating, however, was a direct, avoidable consequence of their own government's austerity policies. An adequately resourced NHS would not have required a significant degree of beyond-the-call-of-duty heroism by healthcare professionals. I should note that I am not making an argument here about the rights and wrongs of resourcing healthcare systems with large numbers of ICU beds, ventilators and other equipment, just in case they might be needed as a result of a new virus making its way through a population. That obviously would require a very significant outlay in terms of resources, and it is unclear to me whether that would indeed be a sound way to spend finite healthcare resources. However, PPE does not constitute hi-tech expensive equipment; all of it can be produced relatively cheaply, and it can be stored in large quantities without taxing a given healthcare system unreasonably financially. That at least seems an uncontroversial claim for any country of the global north. The much vaunted N95 respirator-that probably every country on the globe is trying to purchase at the time of writing in large quantities for healthcare workers-could be obtained for US\$12 for a box of 20 in home improvement stores in the USA, before the pandemic struck. Healthcare systems would have been able to purchase these at a very significant discount. Unsurprisingly, the price of that kind of equipment during pandemic outbreaks rises significantly.

We live in democracies, and we elected politicians who promised us time and again that we could have our cake and eat it. It turns out, unsurprisingly, we cannot have that. There is no reason why doctors, nurses and other healthcare workers should be seen to be professionally obliged to risk their wellbeing during pandemic outbreaks, in the global north, because we chose governments that starved the healthcare delivery infrastructure sufficiently of resources to permit them to do their job safely or with minimal increases to their average on-the-job risk. Elections have consequences.

\section{CONCLUSION}

We should be grateful to any healthcare professional willing to care for COVID-19 patients, in the absence of professionalstandard PPE, but we have no reason to take for granted that there will be one when needed. No healthcare professional can be expected to accept a higher-than-usual degree of risk to their own well-being, simply because we chose not to provide them with the necessary equipment to protect themselves efficiently.

Acknowledgements I thank the anonymous reviewers of this journal for constructive criticism. I owe reference 8 to Professor Michael Ristow, MD.

Contributors I am the sole author of this manuscript.

Funding The authors have not declared a specific grant for this research from any funding agency in the public, commercial or not-for-profit sectors.

Competing interests None declared.

Patient consent for publication Not required.

Provenance and peer review Not commissioned; externally peer reviewed.

This article is made freely available for use in accordance with BMJ's website terms and conditions for the duration of the covid-19 pandemic or until otherwise determined by BMJ. You may use, download and print the article for any lawful, non-commercial purpose (including text and data mining) provided that all copyright notices and trade marks are retained.

\section{REFERENCES}

1 Newman M. COVID-19: doctors' leaders warn that staff could quit and may die over lack of protective equipment. BMJ 2020;368.

2 Lynch L. Queensland hospitals 'very low' on gloves, masks, gowns and told to reuse. Brisbane Times, 2020. Available: https://www.brisbanetimes.com.au/national/ queensland/queensland-hospitals-very-low-on-gloves-masks-gowns-and-told-to-reuse-20200317-p54azh.html [Accessed 2 Apr 2020].

3 Petkova M. Dozens of Bulgarian doctors resign amid COVID-19 crisis. Aljazeera, 2020. Available: https://www.aljazeera.com/news/2020/03/dozens-bulgarian-doctorsresign-covid-19-crisis-200318151643933.html [Accessed 2 Apr 2020].

4 Munhende L. Zimbabwe: COVID-19 - Harare hospital closed, patients discharged as doctors, nurses down tools in demand of protective clothing. AllAfrica, 2020. Available: https://allafrica.com/stories/202003270832.html [Accessed 2 Apr 2020].

5 McNamara A. Nurses across the country protest lack of protective equipment. CBS news, 2020. Available: https://www.cbsnews.com/news/health-care-workers-protestlack-of-protective-equipment-2020-03-28/ [Accessed 2 Apr 2020].

6 FNOMCeO. Elenco dei Medici caduti nel corso dell'epidemia di COVID-19. FNOMCeO 2020. Available: https://portale.fnomceo.it/elenco-dei-medici-caduti-nel-corsodellepidemia-di-covid-19/ [Accessed 2 Apr 2020].

7 List Fallen Coronavirus Heroes (Responses) is maintained. Available: https://docs. google.com/spreadsheets/d/1pFdoZqjnDRaSzJi0JJJ3f5zdb87Q5tL3zc4nGx1nejl/edit\# gid=1744604459 [Accessed 2 Apr 2020].

8 Biermann K, Gutensohn D. Aerzte und Pfleger warnen vor Zwangsarbeit. Zeit 2020. [Epub ahead of print: 2 Apr 2020].

9 British Columbia Ministry of Health Provincial COVID-19 Task Force. COVID-19 ethics analysis: what is the ethical duty of health care workers to provide care during COVID-19 pandemic? 2020. Available: https://www2.gov.bc.ca/assets/gov/health/ about-bc-s-health-care-system/office-of-the-provincial-health-officer/covid-19/duty to_care_during_covid_march_28_2020.pdf [Accessed April 3, 2020].

10 University of Toronto Joint Centre for Bioethics Pandemic Influenza Working Group. Stand on guard for thee: ethical considerations in preparedness for pandemic influenza, 2005. Available: https://web.archive.org/web/20051130054722/http:// www.utoronto.ca/jcb/home/documents/pandemic.pdf [Accessed 3 Apr 2020].

11 Schuklenk U, Zhang EY. Public health ethics and obesity prevention: the trouble with data and ethics. Monash Bioeth Rev 2014;32(1-2):121-40.

12 World Medical Association. International code of medical ethics, 1994. Available: https://www.wma.net/wp-content/uploads/2018/07/Decl-of-Geneva-v1994-1.pdf [Accessed 2 Apr 2020].

13 World Medical Association. Declaration of Geneva, 2017. Available: https://www. wma.net/policies-post/wma-declaration-of-geneva/ [Accessed 2 Apr 2020].

14 Schwartz AR. Doubtful duty: physicians' legal obligation to treat during an epidemic. 60 Stan. L. Rev 2007;657.

15 Veatch RM. Who should control the scope and nature of medical ethics? In: Baker RB, Caplan AL, Emanuel LL, et al, eds. The American Medical Ethics Revolution: How the AMA's Code of Ethics has Transformed Physicians' Relationship to Patients, Professionals, and Society. Baltimore: Johns Hopkins University Press, 1999: 158-70.

16 Schuklenk U. Conscientious objection in medicine: accommodation versus professionalism and the public good. Br Med Bull 2018;126(1):47-56 https:// academic.oup.com/bmb/article/126/1/47/4955771

17 Jakobsson N, Kumlin S. Election campaign agendas, government partisanship, and the welfare state. European Political Science Review 2017;9(2):183-208.

18 McGregor S. Neoliberalism and health care. Int J Consum Stud 2001;25(2):82-9.

19 Donelan K, Blendon RJ, Schoen C, et al. The cost of health system change: public discontent in five nations. Health Aff 1999;18(3):206-16.

20 Sakellariou $D$, Rotarou ES. The effects of neoliberal policies on access to healthcare for people with disabilities. Int J Equity Health 2017;16(1):199. 
21 Mercille J. Neoliberalism and health care: the case of the Irish nursing home sector. Crit Public Health 2018;28(5):546-59.

22 McCarthy N. The countries with the most critical care beds per capita. Forbes, 2020. Available: https://www.forbes.com/sites/niallmccarthy/2020/03/12/the-countrieswith-the-most-critical-care-beds-per-capita-infographic/\#5d0ae11e7f86 [Accessed 2 Apr 2020].

23 Anonymous. NHS winter pressure: hospitals report 99 per cent capacity over festive season as flu season looms. Independent, 2018. Available: https://www.independent. co.uk/news/uk/home-news/nhs-winter-pressure-flu-season-capacity-patientscorridors-a-e-vaccine-a8136231.html [Accessed April 2, 2020].
24 Qualls N, Levitt A, Kanade N, et al. Community mitigation guidelines to prevent pandemic influenza. Morb Mortal Wkly Rep 2017;66(1):1-34.

25 Mosk M, George W. Bush in 2005: 'If we wait for a pandemic to appear, it will be too late to prepare'. ABC News, 2020. Available: https://abcnews.go.com/amp/Politics/ george-bush-2005-wait-pandemic-late-prepare/story?id=69979013 [Accessed 2 Apr 2020].

27 Garrett L. The coming plague: newly emerging diseases in a world out of balance. New York: Farrar, Straus and Giroux, 1994.

27 Storyful. Boris Johnson takes part in nationwide applause to support NHS workers. Yahoo news, 2020. Available: https://uk.news.yahoo.com/boris-johnson-takes-partnationwide-205636024.html [Accessed 2 Apr 2020]. 